\title{
IDEAS ON STATE AND POLITICS IN SERBESTI DURING THE SECOND CONSTITUTIONAL ERA
}

\author{
Mehmet Mert SUNAR ${ }^{*}$
}

\begin{abstract}
The present paper will focus on Serbestî, one of the daily newspapers that were published in the Second Constitutional Period. In this work the political concepts and ideas in Serbestî will be analyzed within the main political framework and concepts of the Second Constitutional Period. Since Serbestî was one of the representatives of opposition to the dominance of the Committee of the Union and Progress, an analysis of Serbestî's content on issues such as the multi-party system, opposition party, and elections will contribute to the understanding of opposition movement in this period. Although Serbestî defended the multi-party system and free elections and supported the participation of the masses in politics in the beginning of the Second Constitutional Era, it gradually adapted the political elitism of the Unionists and advocated for limitations in the participation of the public in politics, especially after the 31 March Incident.
\end{abstract}

Key Words: Second Constitutional Era, politics, newspapers, state administration, opposition.

\section{ÖZET}

\section{Meşrutiyet Döneminde Serbestî Gazetesinde Siyaset ve Devlet Üzerine Görüşler}

Bu çalışmada Ikkinci Meşrutiyet Dönemi'nde yayınlanmış olan Serbestî gazetesi incelenmektedir. Incelemenin temel amacı Serbestî'de yayınlanan makale ve

Asst. Prof., Istanbul Medeniyet University, Faculty of Letters, Department of History, msunar@yahoo.com 
haberlerde yer alan siyasi kavram ve görüşlerin, İkinci Meşrutiyet Dönemi'nin genel siyasi çerçevesi ve tartışmalart içinde değerlendirilmesidir. Serbestî, İttihat ve Terakki Cemiyeti'ne muhalif gazetelerden biri olduğundan, gazetenin çok partili sistem, muhalefet ve seçimler gibi konulardaki görüşlerinin analizi, bu dönemdeki muhalefetin anlaşılması açısından önem taşımaktadır. II. Meşrutiyet'in ilanının hemen ardından Serbesti gazetesi çok partili sistemi ve halkın siyasete katılımını destekler bir tutum sergilerken, 31 Mart Vak'ası sonrasi gazetenin bu tutumunda önemli bir değişiklik yaşanarak İtihatçıların siyasi elitizmine benzer biçimde halkın siyasete katılımının sinırlanması savunulmaya başlanmıştır.

Anahtar Kelimeler: II. Meşrutiyet, siyaset, gazeteler, devlet yönetimi, muhalefet.

\section{Introduction}

In the popular level the period after the Second World War and the rise of Democrat Party are the first things to be remembered when talking about the introduction of multi-party system in Turkey. However Turkey's experience with multi party system, elections, and parliament goes back much earlier than the second half of 1940's. After the suspension of the first Parliament by Abdulhamid II in 1878, the struggle against the authoritarian rule of the Sultan resulted in the second declaration of the Constitution and the re-opening of the Parliament in 1908. This period which continued until 1913 also witnessed the introduction of multi party system in the empire. Although this was not an ideal multi party system in a modern sense, it represents a crucial turning point in the history of the Ottoman Empire. It was also a perfect example comprising many characteristics of multi party system and democracy of the Turkish Republic. Despite its enormous importance this time period was usually overlooked and forgotten in the popular level.

The most important reason of this amnesia was the deliberate policies followed in the earlier periods of the Republic. The founders of the Republic tried to draw strict lines between the new republic and the experience of the Ottoman Empire. They were trying to legitimize the new regime and its policies and one way of doing this was representing the past as completely 'black' and the present as its opposite. Although twenty fourth of July- the day of the second declaration of the Constitution- continued to be commemorated in the first years of the Republic, after 1930 this commemorations started to loose ground and completely ceased in 1935 . $^{1}$ Only after the Second World War and with democratization process new

1 Aykut Kansu, 1908 Devrimi, İstanbul, 1995, pp. XIV-XV. 
academic works started on the subjects of Tanzimat and the Constitutional periods. The turning point was the preparation of a voluminous work Tanzimat which was a offspring of joint work by many academicians who were ordered by Prime Minister İsmet İnönü and the minister of Education to contribute this work which would emphasize the importance of Tanzimat in the modernization process of Turkey. ${ }^{2}$ We still have to wait until the end of 1950's for an awakening of interest among academicians for the Constitutional Period. ${ }^{3}$

Although more works on the Second Constitutional Period seems to be done when compared to the other periods of Ottoman history our knowledge about this era is still considerably limited. Same situation is still valid about the 1914-1918 period. If we consider the progress of printed culture in this era and the quantity of materials, our present knowledge is still at the very beginning.

The present paper will focus on Serbestî, one of the daily newspapers that were published in the Second Constitutional Period. In this work the political concepts and ideas in Serbestî will be analyzed within the main political framework and concepts of the Second Constitutional Period. Since Serbestî was one of the representatives of opposition to the dominance of the Committee of the Union and Progress interpretation of the various concepts such as multi-party system, opposition party, and elections in Serbestî will contribute to the understanding of opposition movement in this period. The period between the second declaration of the Constitution and Babıali Baskını constitutes the boundaries of the work since after Babıali Baskını the authoritative rule of the CUP never let any opposition movement, at least legally. The content of Serbestî after Babıali Baskını testifies this development. After 1913 it is impossible to face with any article or news that criticizes the policies of the CUP. The year 1913 marks the end of short lived multi party system which would be re-established only in 1946. On the other hand the period between the arrival of the Action Army (Hareket Ordusu) and the fall of Unionists with the Savior Officers (Halaskar Zabitan) movement was excluded since Serbestî ceased to be published because of the exile of its owner and editor Mevlanzade Rifat.

2 Tanzimat I, İstanbul, 1940.

3 E. E. Ramsaur, The Young Turks: Prelude to the Revolution, Princeton, 1957; Tar1k Zafer Tunaya, Türkiyede Siyasi Partiler (1859-1952), İstanbul, 1952. 


\section{The Revolution of 1908 and the End of Hamidian Era}

The period after the declaration of the Constitution and the reopening of Parliament with an imperial decree by Abdulhamid II in 1908 witnessed the shift of political power from the palace for the last time in the Ottoman history. In other words Abdulhamid II was the last Ottoman sultan who held the political power and administration in his hands. After 1908 the Sultanate became a symbolic post which nearly had no power upon administration and government of the empire except approbation power. A weak sultan such as Mehmed V would have no role except affirming the decisions of governments. Thus the struggle for the political power changed ground since the control of the Parliament and government now mean the control of the administration.

Parallel to this development the CUP emerged as the only power that could fill the political vacuum with the fall of the Hamidian authority. The main question is why the CUP became the only dominant figure controlling the government and administration? And why the Hamidian authority fell so quickly after the Revolution of 1908?

The declaration of the Constitution was interpreted in very different ways by the population of the empire. At first the provinces of Rumelia enthusiastically embraced the new regime. These were the regions such as Selanik, Kosova and Manastir where the CUP was dominant, this regions were also the territory where the Third Army was stationed. In the capital, however, the people were continuing their daily life as nothing happened. The deep disappointment among a small minority who were against the Hamidian regime can be seen in the memoirs of Huseyin Cahid. ${ }^{4}$ The newspapers were the first which broke thorough the silence. One day after the declaration of the Constitution they disregarded the pre-publication censorship and all the newspapers were published without the approval of the censorship office.

On the other hand the new regime was interpreted in very different way in other provinces, people saw it as an opportunity for removing the unwanted governors and officials in their provinces, everyday new telegraphs requiring the change of governors and official were send to the capital from the various provinces.

In fact the bureaucracy became the main target after the Revolution of 1908. It was identified as the contributor of the authoritative rule of the sultan, and a extensive reform and change among the cadres of bureaucracy was advocated among the supporters of new regime. In fact the bureaucracy 
gained a first hand role in the ruling of the empire in the Hamidian Era, despite the firm control of Abdulhamid over it. The balance of power between military and bureaucracy changed in favor of the latter. The leading role of the army in the disposition of Abdulaziz let Abdulhamid II to control and suppress the military power in his reign.

Starting from the first issues Serbestî questioned the working of bureaucracy. Bureaucrats became the main targets of criticism in the newspaper. In the first issue the aim of newspaper was declared as to control abuses and working of bureaucrats for protecting the interest of public. ${ }^{5}$ The bureaucracy was regarded as rotten since it was full of people who gained their posts by helping the authoritarian regime of the sultan. Thus a complete change rather than reform in the cadres of bureaucracy was necessary according to the newspaper. ${ }^{6}$ In another article the working of bureaucracies in the Ottoman Empire and European countries were compared and the necessity of change was strongly emphasized. ${ }^{7}$

After the opening of Parliament the attitudes of deputies against bureaucracy compromises with this standpoint. The Parliament accepted a sharp decrease in the wages of bureaucrats. ${ }^{8}$ A deputy even argued that all the bureaucrats were useless and should be thrown to the Bosphorus from Sarayburnu.

In contrast to the position of bureaucracy after the Revolution of 1908 the army gained respect and a first hand role in the affairs of the empire. It can be argued that in 1908 the old balance between army and bureaucracy turned upside down. If we disregard the marginal applications of Marxist theory to the Revolution of 1908 which introduce 1908 as a bourgeois revolution, ${ }^{9}$ all the accounts confirm the leading role of the military bureaucracy in the Revolution. But still these works also overestimate the tensions between army and bureaucracy although these seems to work together harmoniously. If we thought more about the balance of power among the integral elements of the state, we would understand that this balance of power changed significantly in the Ottoman history. The main focus should be the matters of finance in which these two powers have

\footnotetext{
5

“Meslek,” Serbestî, 3 Teşrin-i Sani 1324.

6 Serbestî, 9 Teşrin-i Sani 1324, p.1 ; “Bizde Tensikat Olamaz,” Serbestî, 19 Teşrin-i Sani 1324.

7 “Devair-i Hükümet,” Serbestî, 11 Teşrin-i Sani 1324.

8 Ali Fuat Türkgeldi, Görüp İşittiklerim, Ankara, 1949, s. 45.

9 See J. A. Petrosian, Sovyet Gözüyle Jön Türkler, trans. Mazlum Beyhan and Ayşe Hacıhasanoğlu, Ankara, 1974; Aykut Kansu, 1908 Devrimi; Zafer Kars, 1908 Devriminin Halk Dinamiği, İstanbul, 1984.
} 
to interact with each other. The examples clearly demonstrate that army never accepted the control of bureaucracy over its budget. After the 31 March event and disposition of Abdulhamid II the Finance Minister Rifat Bey required that the money which was captured in Yildiz Palace should be returned to the Treasury and then if it is necessary should be given to the army for military expenses. The War minister and the army refused and Rifat Bey resigned from the office. ${ }^{10}$

In another incident in the Parliament Finance Minister Cavid Bey argued that the budget of the army should be open to investigation by the Finance Ministry as it was the case in western countries, The War Minister Mahmud Sevket Pasa strongly refused it and with a patriotic speech he provided the refusal of this proposal in a torrent of applause by deputies. ${ }^{11}$

The relations between army and the CUP seems very ambiguous and in such subject we have not any comprehensive work. However we may venture to say majority of the junior officers in the army were the members of the CUP. This factor became clear during the later periods of the Second Constitution Era. The argument that army officers should cease to engage in politics was mainly advocated by the members of opposition to the CUP. ${ }^{12}$ Seeing this relation between the army and the CUP Serbestî started to argued that the 1908 revolution was not the achievement of the Third army by itself. Without the support of the public the declaration of the Constitution could not take place. ${ }^{13}$

During the 1908 elections the CUP was the only party which seems to have branches in every province of the empire. When we consider the short time period between the declaration of the Constitution and the elections it is astonishing that the CUP completed its organization in such period of time. It can be argued that Abdulhamid's exile policy contributed the presence of the CUP supporters in every province but for completing such an organization we need more than this exiled supporters. The answer lies in the relationships between the army and the CUP, members of the army should have taken an active part in the organization process in the provinces.

Türkgeldi, op. cit., p. 45.

11 Feroz Ahmad, The Young Turks: The Committee of Union and Progress in Turkish Politics, 1908-1914, Oxford, 1969, p. 73.

Especially the leaders of the Halaskar Zabitan movement clearly demanded army officers to withdraw from active politics, and inserted this demand to their ultimatum in 1912. Tarık Zafer Tunaya, Türkiyede Siyasi Partiler(1859-1952), İstanbul, p. 341. 
Ahrar Firkasl, the only opponent of the CUP in the elections of 1908, was away from posing a threat and only small number of its nominees succeeded to enter the Parliament. The CUP was extremely cautious about the nominees of minorities. It forced minority nominees to get approval of the Committee if they wished to be elected. This action was refused by Greeks and resulted in conflict between the CUP and Greeks in İstanbul. During the elections Greeks made demonstrations in Beyoğlu claiming that the CUP intervened the process of elections illegally. ${ }^{14}$

At the end of elections the CUP succeeded in getting majority in the Parliament but the illegal ways which the Committee utilized during the elections let the opponents to criticize the structure and mentality of the CUP. Criticisms concentrated on the structure of the Committee. The CUP was still working as a secret committee using violence against its opponents and intervening the government although it had no legal responsibility. ${ }^{15}$ Long after the opening of the Parliament the opponents of the CUP were still directing these criticisms against the Committee. In fact the CUP kept its structure as a secret committee even after the congress of 1909 when it declared itself as a political party. The question is why did the Committee choose to kept its secret organization and did not take the control of the government directly? There are various explanations to this question. First the CUP was consist of young and inexperienced people whose direct involvement to the government could not be accepted by the majority of public. In the traditional image of a statesman there was no place for young and inexperienced men and this could result in reaction among population and gave opportunity to the opponents of the Committee. ${ }^{16}$ In an article written by a senior member of the army in Serbestî the members of the CUP were regarded as young people without any merit and experience whose rule of the empire would bring more disastrous results than the rule of Abdulhamid II. ${ }^{17}$ Another reason can be found in the advantages of directing the government without responsibility. After the Revolution of 1908 the Committee emerged as a power directing and controlling the working of government. Only after the 31 March incident one or two leading figures entered the government, such as Refik and Cavid Beys.

Serbestî, 16 Teşrin-i Sani 1324, p. 4; "Anasır-1 Osmaniye," Serbestî, 23 Temmuz 1325; For the views of the Unionists on these events see Hüseyin Cahit Yalçin, Siyasi Anılar, pp. 41-42.

Sina Akşin, Jön Türkler ve İttihat ve Terakki, İstanbul, 1987, pp. 148-149.

ibid., p. 86.

17 “Hakikat-i İnkılab," Serbestî, 3 Kanun-1 Evvel 1324. 


\section{Political Rivalry and the Multi-Party System After the 31}

\section{March}

In the period following 24 July 1908 innumerable new groups, organizations and publications arose from the underneath of the falling authoritarian regime of Abdulhamid II. The period of liberty incomparable to any part of the Turkish history continued until the 31 March incident when violence again became an inseparable companion of political life. After that date the political rivalry in the empire oscillated between legal politics and a coup d'etat. This was the result of intolerant approach of the CUP to the multi-party system beside the political tradition of the Ottoman Empire.

In a critical period when the empire was exposed to internal and external threats opposing parties blamed each other for leading the country to fall and dissolution. It can be argued that harshness of political rivalry was also a normal result of this situation of emergency, opposition was always regarded as treason by the party in power. In the minds of the CUP members the mission of the committee crystallized as 'saving the country' from fall and everyone opposing this sacred mission was a traitor who helps the decline of the empire.

When the 31 March uprising was suppressed the forces of the Third and Second Armies was very rigid in punishment of the mutineers, the capital was filled with gallows for the executions. In fact this was a show of military discipline against the rebellious commissioned officers and privateers. The 31 March incident have been interpreted in various ways by specialists and non-specialists writing on the subject. The conventional interpretation regards it as a reactionary movement by Muslim fundamentalists against the modernization of the country. However a closer analysis of the movement reveals the weakness of this simplified explanation. Very different factors and groups came into together in the emergence of the 31 March.

One of the main factors contributing to the events in 31 March was the division within the army. The Ottoman army remained fractionalized between advocates of the old and the new regime. The officers who were educated in military schools supported westernization and parliamentaryministerial control whereas the commissioned officers stayed loyal to the traditional values and the dynasty. The process of elimination against commissioned officers who were loyal to the sultan after 1908 worsened the tensions between these groups. Indeed during the uprising young officers became the main target of mutineers. 
The secularist policies of the Young Turks alarmed and alienated the religious elements. A guiding principle for the Young Turks was the transformation of the society into a state that religion has no dominant role. ${ }^{18}$ The Young Turks was aware the difficulty of implementing such policy and tried to reconcile Islam and materialism. But these arguments were far from persuading ulema and Islamists. The softas joined the rebellious forces and took an active part in the 31 March Incident and the restoration of the Şeriat became the slogan of mutineers. But the religion and the term Şeriat were the normal vehicles for political struggle in the Ottoman Empire for centuries. Islam had played a vital role in the Ottoman society and continued to do so after 1908, and the demand of the Şeriat provided larger audience and legitimization for the uprising. However regarding the movement as a pure fundamentalist reaction means erasing all the political significance of the 31 March Incident.

Another factor was the CUP's growing shadow on the government after the opening of the Parliament. Although the Committee held the majority in the Parliament its organizational structure remained unchanged. The Committee did not transform itself into a political party and this resulted in the questioning of its role in decision making process. The centralist and exclusive policies against non-Turkish elements together with the illegal ways utilized in the elections by the Unionists also contributed the growing opposition against the Committee. In fact in the funeral of the anti-Unionist journalist, Hasan Fehmi, who was probably assassinated by a pro-Unionist officer, it is possible to see the composition of the opposition from the joining groups. Armenian organizations, Dashnaktsutiun and Hunchakian, students of the medreses, Ittihad-ı Muhammedi Cemiyeti, and Albanian Başkim Organization were among the participants. ${ }^{19}$

The centralist and Pan-Turkist policies of the CUP became main target of the criticisms in Serbestî which was defending the idea of Ottomanism. The Unionists were mainly criticized for their Pan-Turkist policies which alienate non-Turkish subjects of the empire. The Pan-Turkist argument was regarded as irrational since there was no race as Turks in the empire. It was not possible to call Muslim population of Anatolia as Turks since these people never called themselves as so. According to Serbestî only the name 'Ottoman' could provide a base for the political and national unity within the empire. ${ }^{20}$ The dynasty would still provide a focus of loyalty for

Şükrü Hanioğlu, The Young Turks in Opposition, New York, 1995, p. 214.

Serbestî, 28 Mart 1325, p. 1.

“Anasır-1 Osmaniye,” Serbestî, 23 Temmuz 1325; “Meclis-i Mebusana Doğru,” Serbestî, 11 Teşrin-i Sani 1324. 
different elements of the Ottoman Empire. It was argued that Turkish nationalism, centered around the Turks in Anatolia, became effective only after 1914 in the face of changing political and demographic factors. ${ }^{21}$ However Turkish nationalism as a ideology was present in the debates among intellectuals long before this date. At the same time it gained a firm ground among the young officers and the members of the CUP and became effective after the Revolution of 1908. The criticisms against the CUP were not groundless if we consider the attitude of the Committee during the 1908 elections. The Committee negotiated with each community and tried to force them to accept the program of the Committee. The Unionist version of Ottomanism was quite different than that of anti-Unionists. The Unionists certainly favored the unity of the empire and the loyalty of the minorities in the name of Ottomanism but only under the leadership of Turkish element.

Although the CUP emerged only political association existing after the suppression of 31 March uprising, the government was still far away from being a 'one party dictatorship'. The Liberal Union Party (Ahrar Firkası) vanished from the political scenery but there was no obstacle for new opposition parties. The multi-party system was still intact and soon the opposition to the Committee started to resurrect under different names. This also shows that the relations between the army and the Committee were remarkably complex.

The effects of growing role of the army in the politics of the Empire became more apparent in the period after 31 March. The Revolution of 1908 had helped the army to break the restrictions and pressure of the Hamidian regime. The army after 1908 was certainly the most important single factor in the politics of the Ottoman Empire. However the structure of the army was far away from being monolithic. There were different groups within the army, junior officers who graduated from the Hamidian military schools were mainly supporting the CUP and the Constitutional regime but the privates and commissioned officers were loyal to the traditional values such as dynasty and Islam. However it was the third group, senior officers, who prevent the domination of the Unionists within the army. The figures such as Mahmud Şevket Paşa and Pertev Paşa were able to control the other two groups and the army. Especially Mahmud Şevket Paşa emerged as the most powerful figure in the politics of the Empire after the suppression of 31 March uprising. Thus the CUP found itself in a position that cooperation or even submission to Mahmud Şevket Paşa was necessary for staying in power. 


\section{Press and Politics in the Second Constitutional Era}

A work on the emergence of newspapers in England and France argues that it was only during periods of intense political crisis in the seventeenth century that political control was either too weak or too disrupted top prevent the appearance of news periodicals. In fact the timing of the rise of newspapers was linked directly to political developments. ${ }^{22}$

The Revolution of 1908 produced a political vacuum in the center of political power along with a freedom of expression incomparable to any period in the Turkish history. The journalists who were the first in perceiving this vacuum reacted it with breaking pre-publication censorship one day after the declaration of Constitution. In a very short period of time following 24 July many newspapers in all languages spoken in the Empire started their publication life. Within two months after the 24th of July two hundred newspapers got the publication permission. Between 1908 and 1909 more than three hundred new newspapers appeared only in the capital. Though some critics regarded this period as a cacophony, in contrast it can be regarded as a period of freedom free from pressure of state or any dominant group.

Many of these newspapers and periodicals could not continue their life more than a few issues. The difficulties of financing and low demand from the public hardened conditions of printing newspaper. Backing of a community or a political group became necessary for financing a newspaper. Thus from the very beginning publication of a newspaper was heavily loaded with political objects. Newspapers emerged as an important tool in the political struggle for both the groups in power and the ones in opposition. Starting from the publication of Le Spectateur Oriental by Alexandre Blacque in 1821 and Takvim-i Vekayi in 1831 the Ottoman government was aware of the importance of newspaper for political propaganda in domestic and international arena. Le Spectateur Oriental had defended the claims of the Ottoman government in the crisis leading to Greek Rebellion whereas Takvim-i Vekayi made the propaganda of the dynasty and the government in the domestic politics. The rise of Young Ottoman opposition in abroad introduced the use of newspaper against the governing elite. One generation after the Young Ottomans the use of newspaper in political opposition was also utilized by the Young Turks.

The readership of newspapers in the Ottoman Empire was restricted with governing elite who were educated in the new schools providing

22 Bob Harris, Politics and the Rise of the Press: Britain and France, 1620-1800, London and New York, 1996, p. 26. 
qualified personnel to the military and the bureaucracy. A further group should be the ulema and the students of medreses. Unlike Europe where newspapers emerged as a political vehicle of bourgeoisie against the governing elite, in the Ottoman Empire the emergence of newspapers can be identified with the state or the struggle within the ruling elite.

The Second Constitutional Era did not bring any significant change to this characteristic of the press, it can be argued that readership of newspapers was limited to the ruling elite. Individual purchase of newspapers was probably concentrated quite up the social ladder. Thus it is not astonishing that domestic and international politics in comparison to other subjects constituted the main problems discussed in newspapers.

A close look to the example of Serbestî reveals that domestic and international politics constitutes nearly all its contents. It is hard to find any articles on subjects such as economics, education or sociology. Instead the articles on problems of the Constitutional regime, bureaucracy and the crisis in the international arena were the daily content of the newspaper. We can venture to argue that these subjects compromises the interests of Serbestî's reader profile. From an analysis of known authorship of readers' letters in Serbestî it can be suggested that the letters were generally written by bureaucrats, members of legal profession and officers in the army. The dominance of political elitism in the articles of Serbestî can be connected to the mentality of the period. In fact elitists ideas were shared among all the intellectuals of the era regardless of their political standpoint. From the liberals to the Unionists the distrust to the masses was a common point. All of them visualized the reform as a process in which an educated and professional group of statesmen find remedies to the problems of the country. They believed that once such individuals get power in the government the rule of law and rationality in the state apparatus would be established, corruption and decline of the empire would be prevented. Developing such an elite to govern the state was a determining aspiration for the Young Turks from the beginning. They never envisioned participation of the masses in policy-making process. ${ }^{23}$

The decline of the Empire was related to the non-existence of qualified statesmen and the term kaht- $r$ rical was commonly used in the press and political debates. The example of Serbestî reveals no exception to this attitude of intellectual elite. The need for a ruling elite which owns necessary skills in administration and politics was a dominant argument in 
the columns of Serbestî. ${ }^{24}$ Older figures of Hamidian regime, such as Kamil and Said Paşas was strongly denounced as incapable of any energetic skills and proficiency for rational administration. ${ }^{25}$ The necessity for young and capable figures for the state's administration was insistently put forward by the authors of the articles in Serbestî.

An analysis of the articles in Serbestî from 1908 to 1913 also reveals a considerable change in the approach to role of the masses in politics. Aftermath of the Revolution the masses were saluted as the builder of the Constitutional regime and freedom. The government and bureaucracy were presented as the servants of the Ottoman citizens who have natural rights for the participation to politics and administration. The critics on the Hamidian regime focuses on its authoritarian character and the idea that immaturity of the public for taking part in government. The concept of hikmet-i hükümet, a term used to emphasize the inability of the masses to understand high politics and administration, was regarded as a curtain for corruption in the government. ${ }^{26}$ Thus the interests and the rights of the masses emerged were presented as the main focus in Constitutional regimes. Along with the rights of the masses the concept of free press as a political value and inseparable part of the rule of people was matured in Serbestî. ${ }^{27}$

However we observe a considerable change in confidence to the masses in Serbestî after it started to re-publish in 1912. Aftermath of the 31 March Mevlanzade Rifat, the owner and editor of Serbestî, had to escape abroad since he was blamed as one of the provocateurs of the uprising. He was only able to publish ten more issues of Serbestî in Paris with the help of Şerif Paşa and then moved to Greece where he published the newspapers Faruk and Cihad. Serbestî only started to be re-published after the Ahmet Muhtar Paşa government came into power with the fall of Unionists in 1912. ${ }^{28}$ However this time Serbestî's approach to the sovereignty of the masses was very different than the period before 31 March and the exile of Mevlanzade. Although the idea of popular sovereignty was mentioned in the columns of the newspaper more and more the concept 'duties of the masses' was widely used. ${ }^{29}$ The citizens according to Serbestî have to know their

"Bizde Hükümet Adamı Var Mıdır?," Serbestî, 17 Eylül 1325; “Bu Derece Ricalden Mahrum Muyuz?,” Serbestî, 20 Temmuz 1328.

“Ahenk-i İdare,” Serbestî, 11 Teşrin-i Sani 1324; Serbestî, 21 Şubat 1324, p. 3.

“Tezebzüb-i İdare,” Serbestî, 28 Mart 1324.

“Siyasat,” Serbestî, 10 Kanun-1 Sani 1325.

Mevlanzade Rifat, Ittihat ve Terakki İktidarı ve Türkiye Inkilabının İcyüzü, ed. A.N. Galitekin, İstanbul, 1993, pp. II-III.

“Hadd-i Maruf,” Serbestî, 26 Temmuz 1328; “Ahenk-i İdare,” Serbestî, 3 Ağustos 1328. 
duties and keep away from active politics. The politics and administration of the country should be left to the individuals who have necessary qualifications and education. ${ }^{30}$ Also a change in the idea of free press is evident, journalists were warned not to provoke public opinion which was considered as immature and irrational. ${ }^{31}$ Thus the elitism in Serbestî becomes stronger further with the distrust to the masses and their role in politics. On the other hand a close look to Serbestî still clarifies the different approach to multi-party system than that of the Unionists. The existence of opposition parties was regarded as an essential characteristic of a constitutional regime. The newspaper rigidly criticizes intolerant and illegal actions of the CUP against its opponents. The fall of the CUP during the crisis of 1912 was related to that characteristic of the Committee and ignorance of public opinion was presented as the main cause of this fall. ${ }^{32}$

\section{Conclusion}

In the period under review the Ottoman Empire passed through transformation in nearly all sphere of life. The question, whether the date 1908 represents a breaking point put forward the problem of continuity and discontinuity in the Turkish history. Without a doubt there are various aspect of this question. This work only dealt with the political side of it concentrating on a chosen newspaper and a time period. Thus it offers partial and incomplete answers to the problem of state and politics in the Second Constitutional Era.

If we consider that the balance of power within the state apparatus changed from time to time in significant ways in the Ottoman Empire, the period after 1908 emerges as a time when the locus of power shifted to the military from the bureaucracy under the control of Abdulhamid II. Indeed the Ottoman-Russian War in 1877-1878 was a turning point when the disastrous defeat of the Ottoman army against Russians resulted in the decline of the army's prestige and power in domestic politics. On contrary the Revolution of 1908 resulted in increase of its prestige and image among the public. The role of the army in domestic politics again became an inevitable fact in the Ottoman Empire.

Though the military retained the power to veto any measures it did not approve of it let the civilians to govern the Empire. The multi party system and constitutional regime continued to exist even after severe crisis

“Hadd-i Maruf,” Serbestî, 26 Temmuz 1328.

“Ahval-i Hazıra Nikbin Olalım,” Serbestî, 18 Temmuz 1328.

32

“İstiklal-i Milli,” Serbestî, 21 Temmuz 1328. 
and conflict. It was argued that after 1908 the Unionists faced with the alternative of keeping the old regime and power structures intact and establishing new ones. Lacking the will to follow the first course they naturally chose the latter. ${ }^{33}$ However this fatalist explanation ignores the motives of the Revolution in 1908. Indeed the constitutional regime and parliament representing the sovereignty of the people was shared values among the Young Turks whatever were their origin. The individuals who participated the opposition against the sultan believed that the application of these concepts was the only was for the survival of the Empire. On the other hand these were symbols with opaque meanings and interpretation. The political elitism and the idea of omnipotent state were still dominant in their mentality. They supported a reform policy in which a small group of educated and cultured individuals would guide politically immature and ignorant masses on the way of civilization. A detailed analysis of the politics and state institutions in the Second Constitutional Era will probably reveal striking similarities with the political experience of modern Turkey in democracy and multi party system.

\section{BIBLIOGRAPHY}

\section{A. NEWSPAPERS}

Serbestî (İstanbul), 1324-1328 (1908-1913)

\section{B. BOOKS AND MEMOIRS}

Ahmad, Feroz. The Young Turks: The Committee of Union and Progress in Turkish Politics, 1908-1914, Oxford, 1969.

Akşin, Sina. Jön Türkler ve İttihat ve Terakki, İstanbul, 1987.

Akşin, Sina. "Jön Türkler,"Tanzimat'tan Cumhuriyet'e Türkiye Ansiklopedisi, c. V., 832-843.

Birinci, Ali. Hürriyet ve İtilaf Fırkası, İstanbul, 1990.

Hanioğlu, Şükrü. The Young Turks in Opposition, New York, 1995.

Harris, Bob. Politics and the Rise of the Press: Britain and France, 16201800, London and New York, 1996

Kansu, Ayku. 1908 Devrimi, İstanbul, 1995.

Kars, Zafer. 1908 Devriminin Halk Dinamiği, İstanbul, 1984.

Kuran, Ahmet Bedevi. Inkılap Tarihimiz ve Ittihat ve Terakki, İstanbul, 1948. 
Lewis, Bernard. The Emergence of Modern Turkey, Oxford, 1961.

Mardin, Şerif. Continuity and Change in the Ideas of Young Turks, 1969.

Petrosian, J. A. Sovyet Gözüyle Jön Türkler, trans. Mazlum Beyhan and Ayşe Hacıhasanoğlu, Ankara, 1974.

Ramsaur, E. E.. The Young Turks: Prelude to the Revolution, Princeton, 1957.

Rifat, Mevlanzade. Ittihat ve Terakki İktidarı ve Türkiye Inkilabının İçüzü, ed. A.N. Galitekin, İstanbul, 1993.

Toprak, Zafer. İttihat-Terakki ve Devletçilik, İstanbul, 1995.

Tökin, F.Hüsrev. Türk Tarihinde Siyasi Partiler ve Siyasi Düşüncenin Gelişmesi, İstanbul, 1965.

Tunaya, Tarık Zafer. Türkiye’de Siyasi Partiler 1859-1962, İstanbul, 1952.

Türkgeldi, Ali Fuat. Görüp İsittiklerim, Ankara, 1951.

Yalçın, Hüseyin Cahit. Siyasal Anılar, haz. Rauf Mutluay, İstanbul, 1976. 